\title{
Identification of Novel Type III Secretion Effectors in Xanthomonas oryzae pv. oryzae
}

\author{
Ayako Furutani, ${ }^{1}$ Minako Takaoka, ${ }^{2}$ Harumi Sanada, ${ }^{2}$ Yukari Noguchi, ${ }^{3}$ Takashi Oku, ${ }^{2}$ Kazunori Tsuno, ${ }^{4}$ \\ Hirokazu Ochiai, ${ }^{1}$ and Seiji Tsuge ${ }^{3}$ \\ ${ }^{1}$ National Institute of Agrobiological Sciences, Tsukuba, Japan; ${ }^{2}$ Laboratory of Molecular Plant Pathology, Faculty of Life \\ and Environmental Sciences, Prefectural University of Hiroshima, Shobara, Japan; ${ }^{3}$ Laboratory of Plant Pathology, \\ Graduate School of Agriculture, Kyoto Prefectural University, Kyoto, Japan; ${ }^{4}$ Faculty of Agriculture, Miyazaki University, \\ Miyazaki, Japan
}

Submitted 4 July 2007. Accepted 11 September 2008.

\begin{abstract}
Many gram-negative bacteria secrete so-called effector proteins via a type III secretion (T3S) system. Through genome screening for genes encoding potential T3S effectors, 60 candidates were selected from rice pathogen $\mathrm{Xan}$ thomonas oryzae pv. oryzae MAFF311018 using these criteria: i) homologs of known T3S effectors in plant-pathogenic bacteria, ii) genes with expression regulated by hrp regulatory protein $\mathrm{HrpX}$, or iii) proteins with $\mathrm{N}$-terminal amino acid patterns associated with T3S substrates of Pseudomonas syringae. Of effector candidates tested with the Bordetella pertussis calmodulin-dependent adenylate cyclase reporter for translocation into plant cells, 16 proteins were translocated in a T3S system-dependent manner. Of these 16 proteins, nine were homologs of known effectors in other plant-pathogenic bacteria and seven were not. Most of the effectors were widely conserved in Xanthomonas spp.; however, some were specific to $X$. oryzae. Interestingly, all these effectors were expressed in an $\mathrm{HrpX}$ dependent manner, suggesting coregulation of effectors and the T3S system. In $X$. campestris pv. vesicatoria, HpaB and $\mathrm{HpaC}$ (HpaP in $X$. oryzae pv. oryzae) have a central role in recruiting $\mathrm{T} 3 \mathrm{~S}$ substrates to the secretion apparatus. Secretion of all but one effector was reduced in both $\mathrm{HpaB}^{-}$ and $\mathrm{HpaP}^{-}$mutant strains, indicating that $\mathrm{HpaB}$ and $\mathrm{HpaP}$ are widely involved in efficient secretion of the effectors.
\end{abstract}

Many gram-negative bacteria of plants and animals use a protein secretion system, a so-called type III secretion (T3S) system, to cause disease on their respective hosts (Alfano and Collmer 1997; Büttner and Bonas 2002; Cornelis and Van Gijsegem 2000). Through a T3S apparatus, bacteria directly inject effector proteins into host cells, which are considered to be the primary virulence factors. Once inside the host cells, effectors are predicted to modulate host defense signaling pathways and to induce disease by interfering with host cell functions (Staskawicz et al. 2001). Bacteria secrete not only virulence factors but also factors to induce disease resistance via a T3S system. Bacteria generally appear to produce various sets of effectors and, thus, the function of effectors may contribute to diversity in bacterial pathogenicity. In plant-

Corresponding author: S. Tsuge; Telephone: 81-75-703-5614; Fax: 81-75703-5614; E-mail: s_tsuge@love.kpu.ac.jp

*The $\boldsymbol{e}$-Xtra logo stands for "electronic extra" and indicates four supplemental tables are published online. pathogenic bacteria, the components of the T3S system are encoded by hypersensitive response and pathogenicity ( $h r p$ ) genes (Alfano and Collmer 1997). Mutations in hrp genes generally abolish pathogenicity in susceptible host plants and the induction of the hypersensitive response (HR) in resistant host and nonhost plants. Despite the importance of a T3S system, however, the precise functions of most of the substrates during pathogenesis have not yet been elucidated.

In plant-pathogenic bacteria, effectors have been identified mainly by cloning the genes based on the avirulence phenotype, sequence analysis of extracellular proteins secreted through a T3S apparatus, and characterization of genes located in the Hrp pathogenicity island (Alfano and Collmer 2004; ZwieslerVollick et al. 2002). However, a breakthrough came with genome-sequencing projects of several plant-pathogenic bacteria for the past several years (Buell et al. 2003; da Silva et al. 2002; Feil et al. 2005; Joardar et al. 2005; Ochiai et al. 2005; Salanoubat et al. 2002; Thieme et al. 2005). Many of the known T3S effectors share several characteristics: i) expression coregulated with hrp genes (Tang et al. 2006) and ii) N-terminal amino-acid patterns typical of T3S substrates, although the precise secretion signal remains unknown (Schechter et al. 2004). Computer-based analyses using these criteria have enabled the screening of a large number of T3S effector candidates in Pseudomonas syringae pathovars and Ralstonia solanacearum. The translocation of effector candidates has been examined using efficient reporters such as calmodulin-dependent adenylate cyclase (Cya) from Bordetella pertussis (CasperLindley et al. 2002; Cunnac et al. 2004; Schecher et al. 2006; Sory and Cornelis 1994) and avirulence gene products (e.g., AvrRpt2) lacking the T3S signal sequence (Petnicki-Ocwieja et al. 2002; Vencato et al. 2006; Zwiesler-Vollick et al. 2002). Guttman and associates (2002) and Roden and associates (2004) also identified effectors by random insertion with transposons containing avirulence (avr) genes, which lack the secretion signal, followed by an Avr-based assay for the translocation of gene products fused with Avr into plant cells.

In addition to the translocation signal that is predicted to reside in the $\mathrm{N}$-terminal regions of T3S substrates, cytoplasmic chaperones also play important roles in targeting effectors to the T3S pathway, although they have not been found for all T3S effectors (Alfano and Collmer 2004; Tampakaki et al. 2004). Binding to their cognate effectors, T3S chaperones stabilize the effectors or keep them partially unfolded and help effectors compete for access to the T3S apparatus (Page and Parsot 2002; Stebbins and Galan 2001). T3S chaperones can be divided into classes based on whether they interact with one 
specific effector or with multiple effectors (Cornelis and Van Gijsegem 2000; Parsot et al. 2003). In P. syringae, chaperones that interact mainly with a specific effector have been identified, whereas in Xanthomonas campestris pv. vesicatoria, the global chaperones $\mathrm{HpaB}$ and $\mathrm{HpaC}$ interact with multiple effectors (Büttner et al. 2004, 2006; Gürlebeck et al. 2006).

$X$. oryzae pv. oryzae is the causal agent of bacterial leaf blight of rice with considerable genetic diversity (Adhikari et al. 1995; Niño-Liu et al. 2006; Vauterin et al. 1995). Like other plantpathogenic bacteria, hrp genes have crucial roles for pathogenicity in the bacterium (Kamdar et al. 1993). Therefore, identification of T3S effectors of this bacterium is a key step toward a comprehensive understanding of T3S system-mediated plantbacterium interactions. X. oryzae pv. oryzae harbors multiple genes for T3S effectors of the transcription activator-like (TAL) effector family, also called the avrBs3/pthA family (Lee et al. 2005; Niño-Liu et al. 2006; Ochiai et al. 2005; Salzberg et al. 2008; Wu et al. 2007; Yang et al. 2006). The TAL effector family has several characteristic features: i) a central region of near-perfect 34-amino-acid repeats that vary in number, ii) highly conserved C-terminal nuclear localization signals, and iii) C-terminal acidic transcription activator-like domains (Leach and White 1996). AvrXa7, AvrXa10, and AvrXa27 are representative effectors that elicit disease resistance in hosts with corresponding resistance genes and thereby function as determinants of racecultivar specificity (Gu et al. 2005; Yang et al. 2000; Zhu et al. 1998). Additionally, two TAL effectors have been shown to control the induction of the host rice genes during infection (Sugio et al. 2007). However, few studies on types of effectors other than TAL have been reported in X. oryzae pv. oryzae.

As mentioned, the expression of some portions of known effectors is coregulated with $h r p$ genes, and hrp regulatory proteins seem to directly regulate expression of the effectors (Tang et al. 2006). In xanthomonads, an AraC-type transcriptional activator, HrpX, is known as a regulator of hrp genes (Oku et al. 1995; Wengelnik and Bonas 1996). Many of the HrpX-regulated genes (HrpX regulons) possess the conserved cis-regulatory element, a plant-inducible promoter (PIP) box (TTCGB-N15-TTCGB, B, C/G/T) (Fenselau and Bonas 1995; Tsuge et al. 2005). In $X$. campestris pv. vesicatoria, specific binding of HrpX to a PIP box has been demonstrated (Koebnik et al. 2006). Recently, we found an additional conserved cisacting regulatory element, a -10 box-like sequence (YANNDT: $\mathrm{Y} ; \mathrm{C} / \mathrm{T}, \mathrm{N} ; \mathrm{A} / \mathrm{T} / \mathrm{G} / \mathrm{C}, \mathrm{D}, \mathrm{A} / \mathrm{T} / \mathrm{G})$ that resembles the binding motif of the RNA polymerase $\sigma^{70}$ factor and is located 30 to $32 \mathrm{bp}$ downstream of the PIP box (Furutani et al. 2006). By searching for these cis elements in the genome sequence, we have identified several novel HrpX regulons (Furutani et al. 2006) in which T3S effector genes might be included.

In this study, as the first step to investigate T3S system-mediated interactions between plants and $X$. oryzae pv. oryzae at a molecular level, we screened candidate genes encoding a potential substrate for a T3S system in accordance with the following criteria: i) genes encoding proteins that are homologous with known effectors of other bacteria, ii) HrpX regulons preceded by two cis elements, or iii) proteins with an N-terminal amino acid composition similar to known effectors. Using a Cya reporter system, we examined the T3S system-dependent translocation of the selected effector candidates and identified 16 T3S effectors.

\section{RESULTS}

\section{Screening of effector candidates}

from the genome database of $X$. oryzae pv. oryzae.

Many effectors secreted through a T3S system have been identified in plant-pathogenic bacteria. In this study, open reading frames (ORF) having putative products homologous to effectors of $P$. syringae strains (refer to $P$. syringae Genome Resources home page) and $X$. campestris pv. vesicatoria (Gürlebeck et al. 2006) were selected as $X$. oryzae pv. oryzae effector candidates. A BLAST search against the $X$. oryzae pv. oryzae MAFF311018 genome database revealed that the predicted products of at least 12 ORF (XOO0103, XOO0148, XO00261, X000315, XOO0835, XOO1914, XOO2402, XOO2875, XOO3150, XOO3222, XOO4042, and XOO4208) share homology with known Hrp outer proteins (Hops) of $P$. syringae strains and Xanthomonas outer proteins (Xops), although some of them have limited and partial homology (Supplementary Table S1).

Many effectors are regulated in expression by Hrp regulatory genes in plant-pathogenic bacteria (Tang et al. 2006). In xanthomonads, HrpX is known as a regulator of other hrp genes (Oku et al. 1995; Wengelnik and Bonas 1996). In our previous work (Furutani et al. 2006), we identified nine HrpX regulons (X000804, X001669, XOO2877, X002967, XOO3803, XOO3844, XOO4134, XOO4208, and XOO4367) preceded by both a PIP box and a -10 box-like motif, which are commonly located in the promoter region of $h r p B, h r p C, h r p D$, and $h r p E$ transcriptional units. Therefore, these ORF were also included as effector gene candidates (Supplementary Table S2).

Although targeting signals for a T3S system that are common to bacteria have not been found, Schechter and associates (2004) suggested several characteristic features in the $\mathrm{N}$ terminal structure of Hop proteins in P. syringae pv. tomato; high content (more than 10\%) of Ser in the first 50 amino acids (aa), no Asp or Glu residues in the first 12 aa, and an aliphatic amino acid (Ile, Leu, or Val) or Pro at the third or fourth position. These features are applicable to known T3S substrates of $X$. oryzae pv. oryzae, Hpa1, HrpE1, and HrpF (Furutani et al. 2003, 2004), except that HrpE1 has a Glu at the second position. Therefore, here we screened for ORF that would encode proteins with the three features. More than 200 ORF were selected, including transposable elements, flagellar proteins, ribosomal proteins, membrane proteins, and proteins with type II signal peptides, which are unlikely to be T3S effectors and removed from our list. We also removed candidates that might be the second or latter genes in the operon because of a technical reason, except XOO0103, which encodes a homolog of a known effector XopF1 and is preceded by $\mathrm{XOO0104}$ in the probable same operon. Finally, we selected 44 ORF encoding proteins with a predicted N-terminal amino acid pattern typical of T3S substrates (Supplementary Table S3).

Ultimately, based on the three criteria described, we selected $60 \mathrm{ORF}$ as effector gene candidates from the genome database of $X$. oryzae pv. oryzae MAFF311018 (Fig. 1).

\section{Identification of T3S effectors.}

The T3S system-dependent translocation of 60 effector candidates was investigated using the $B$. pertussis Cya translocation reporter assay (Sory and Cornelis 1994). Because an Nterminal region of effectors is generally required for secretion via a T3S apparatus, the $5^{\prime}$-coding region (at least $371 \mathrm{bp}$ ) of each effector gene candidate and the preceding putative promoter region (at least $215 \mathrm{bp}$ ) was amplified with appropriate primers and cloned into pHMCya-1, pHMCya or pHMCya+1, where an effector::Cya fusion protein would be expressed. $X$. oryzae pv. oryzae wild-type strain $\mathrm{T} 7174 \mathrm{R}$ was transformed with each plasmid, then infiltrated into tomato leaves, where $X$. oryzae pv. oryzae induces HR hrp dependently. The translocation of the fusion proteins into tomato leaf cells was investigated by measuring the level of cAMP (Casper-Lindley et al. 2002). In all, 16 transformants harboring a plasmid with one of 
the ORF (XOO0037, XOO0103, XOO0148, XOO0315, XOO1488, XOO1669, XOO2210, ХOO2402, ХOO 2875 ,

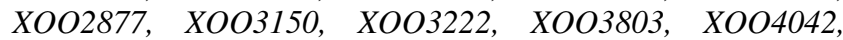
$X O O 4134$, and $X O O 4208$ ) fused with cya led to an increase in cAMP level in the infiltrated areas (Table 1), while others had a lower cAMP level similar to a transformant with an empty vector. Because adenylate cyclase activity depends on the presence of calmodulin, which is present in eukaryotic plant cells but not in prokaryotic bacterial cells, high levels of cAMP reflect the translocation of fusion proteins into plant cells.

To investigate whether the translocations of the proteins are dependent on a T3S system of the bacteria, we transformed a T3S system-deficient strain, $74 \mathrm{HrcV}:: \mathrm{Km}$, which has a transposon insertion in $h r c V$ encoding a component of secretion apparatus (Furutani et al. 2003), with the plasmids harboring an effector candidate::cya fusion gene and infiltrated tomato leaves with the transformants. In the case of 74HrcV::Km-derived transformants, less cAMP accumulated, similar to the wild-type strain with an empty vector (Table 1). These results indicate that the fusion proteins are translocated into the plant cells through a T3S pathway and suggest that the $16 \mathrm{ORF}$ encode T3S effector proteins. The various levels of cAMP accumulation among effector::Cya fusion proteins might reflect differences in the amount of translocation of each effector. However, the possibility cannot be excluded that the promoter regions or 5 -coding regions of effector genes fused with a cya gene were insufficient for complete expression or secretion.

We also examined the translocation of effector::Cya fusion proteins into rice leaf cells during infection by $X$. oryzae pv. oryzae. Three days after inoculation, cAMP levels were high in rice leaf sections inoculated with transformants with each of the various effector::cya genes although cAMP was undetectable in samples inoculated with bacteria with the empty vector (Fig. 2). The results suggest that, during infection, all 16 effectors are transported into rice leaf cells. Because T3S systemdeficient strains in rice leaves grew much less than the wildtype strain, we did not test these strains.

\section{i) Effector homologs}

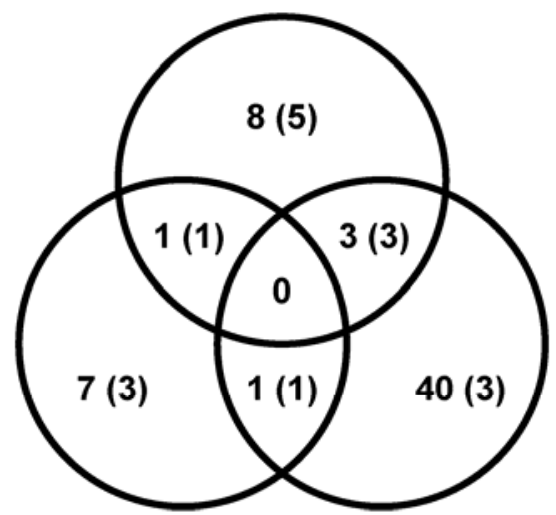

\section{ii) HrpX regulons with consensus motifs

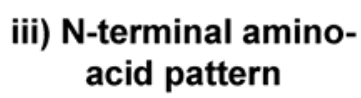

Fig. 1. Number of type III secretion (T3S) effector candidates examined in this study. We screened candidates from the genome database for Xanthomonas oryzae pv. oryzae MAFF311018 on the basis of i) homologs with known effectors in Pseudomonas syringae pathovars and X. campestris pv. vesicatoria; ii) HrpX regulons with two consensus motifs, a plantinducible promoter box and a -10 box-like sequence, in the putative promoter region; and iii) possession of an $\mathrm{N}$-terminal amino-acid patterns typical of T3S effectors. The number in each group is shown; the number of T3S effectors identified in this study is in parentheses.
Expression of effector genes is regulated by Hrp regulatory gene HrpX.

When 16 T7174R-derived transformants with an effector::cya fusion gene were incubated in the $h r p$-inducing medium XOM2, the fusion proteins were expressed for all transformants as measured by the assay for adenylate cyclase activity in bacterial extracts, although the expression levels varied considerably among the effector genes (Table 2). We previously showed the HrpX-dependent expression of five effector genes, XOO1669, XOO2877, XOO3803, XOO4134, and XOO4208 (Furutani et al. 2006). Here, we investigated the involvement of $\mathrm{HrpX}$ in the expression of 11 other effector genes. Plasmids harboring one of the various effector::cya fusion genes were introduced into the $h r p X^{-}$strain, 74HrpX::Km, and the expression of fusion genes was examined by measuring the adenylate cyclase activity in extracts from transformants after an 18-h incubation in XOM2. The activity of eight transformants, except for XOOO315, XOO2402, and XOO2875, was much lower compared with the wild-type strains with the corresponding plasmids (Table 2). We also conducted semiquantitative reversetranscription polymerase chain reaction (RT-PCR) analysis to test whether the expression of XOO0315, XOO2402, and XOO2875 is, indeed, HrpX independent. The specific DNA fragment corresponding to the internal sequence of each effector gene was amplified from strain T7174R incubated in XOM2 but not from strain $74 \mathrm{HrpX}:: \mathrm{Km}$ (Fig. 3). These results suggest that expression of all the effectors that we identified in this study is regulated by Hrp regulatory protein HrpX. The plasmids harboring the fusion genes (XOO0315, XOO2402, and XOO2875) may contain incomplete promoter regions, which may be the reason for the inconsistent results between the Cya reporter assay and RT-PCR analysis for these effector genes.

\section{Involvement of $\mathrm{HpaB}$ and $\mathrm{HpaC}$ in effector secretion.}

Büttner and associates (2006) reported that $\mathrm{HpaB}$ and $\mathrm{HpaC}$ play a crucial role in recruiting some parts of the T3S substrates to the secretion apparatus in X. campestris pv. vesicatoria. We investigated whether secretion of the effectors identified here was affected by the lack of $\mathrm{HpaB}$ or $\mathrm{HpaP}$ (HpaC in $X$. campestris pv. vesicatoria) in $X$. oryzae pv. oryzae. Each

Table 1. Levels of cAMP in tomato leaves $10 \mathrm{~h}$ after infiltration with either T7174R or 74HrcV::Km harboring an effector candidate fused with cya

\begin{tabular}{llrc}
\hline & & \multicolumn{2}{c}{ cAMP (nmol/mg protein) } \\
\cline { 3 - 4 } Gene ID $^{\mathbf{a}}$ & Homolog $^{\mathbf{c}}$ & T7174R & 74HrcV::Km \\
\hline XOO0037 & & 12.55 & 0.09 \\
XOO0103 & XopF1 & 171.55 & 0.12 \\
XOO0148 & AvrBs2 & 149.65 & 0.35 \\
XOO0315 & XopN & 15.74 & 0.11 \\
XOO1488 & & 349.39 & 0.20 \\
XOO1669 & & 12.73 & 0.15 \\
XOO2210 & & 119.71 & 0.14 \\
XOO2402 & (HopAS1) & 1.56 & 0.09 \\
XOO2875 & Early chrolosis factor & 5.67 & 0.08 \\
XOO2877 & & 44.04 & 0.09 \\
XOO3150 & (XopN) & 201.12 & 0.25 \\
XOO3222 & XopP & 141.13 & 0.13 \\
XOO3803 & & 468.29 & 0.39 \\
XOO4042 & XopX & 225.16 & 0.54 \\
XOO4134 & & 364.53 & 0.29 \\
XOO4208 & XopQ & 150.90 & 0.18 \\
Empty vector & & 0.07 & ND $^{\mathrm{d}}$ \\
\hline
\end{tabular}

${ }^{a}$ Mean of three replicates are shown.

$\mathrm{b}$ The $5^{\prime}$ region of each gene with the upstream putative promoter region was fused with cya.

${ }^{c}$ Homologs with the highest similarity with each gene product are indicated. Parentheses represent proteins with partial homology.

${ }^{\mathrm{d}}$ Not determined. 
effector::cya fusion gene was introduced into the $h p a B^{-}$and $h p a P^{-}$strains, the transformants were infiltrated into tomato leaves, and then cAMP was measured at $8 \mathrm{~h}$ after infiltration. Less cAMP accumulated in leaves infiltrated with strains lacking either $\mathrm{HpaB}$ or HpaP for all effectors but XOO0148 compared with T7174R-derived transformants (Fig. 4). On the other hand, in the hrp-inducing medium, similar or higher levels of fusion proteins accumulated in both $\mathrm{HpaB}$ and $\mathrm{HpaP}$ mutants compared with the wild-type background (Table 2). These results suggest that $\mathrm{HpaB}$ and $\mathrm{HpaP}$ are not involved in expression of the effector genes tested and that they are involved in the efficient secretion of the effectors, although they are not indispensable.

\section{DISCUSSION}

Plant-pathogenic bacteria generally possess several dozen T3S effectors. TAL effectors (AvrBs3/PthA family proteins) are well-characterized T3S effectors that are conserved in several species (or pathovars) of xanthomonads (Bonas et al. 1989; Hopkins et al. 1992; Swarup et al. 1991). X. oryzae pv. oryzae has many copies of this type of effector: 16 ORF in Japanese strain MAFF311018, six in Korean strain KACC10331, and 19 in Philippines strain PXO99A (Lee et al. 2005; Ochiai et al. 2005; Salzberg et al. 2008). Several of them have proved to be important for plant-pathogen interactions (Gu et al. 2005; Sugio et al. 2007; Yang et al. 2000; Zhu et al. 1998). On the contrary, little is known about the role of other types of effectors in this bacterium. Here, we identified 16 non-TAL effectors: nine of these effectors (XOO0103, XOO0148, XOO0315, XOO2402, XOO2875, XOO3150, XOO3222, XOO4042, and XOO4208) share homology with previously identified T3S effectors in other plant-pathogenic bacteria, and seven effectors (XOO0037, XOO1488, XOO1669, XOO2210, XOO2877, XOO3803, and XOO4134) do not.

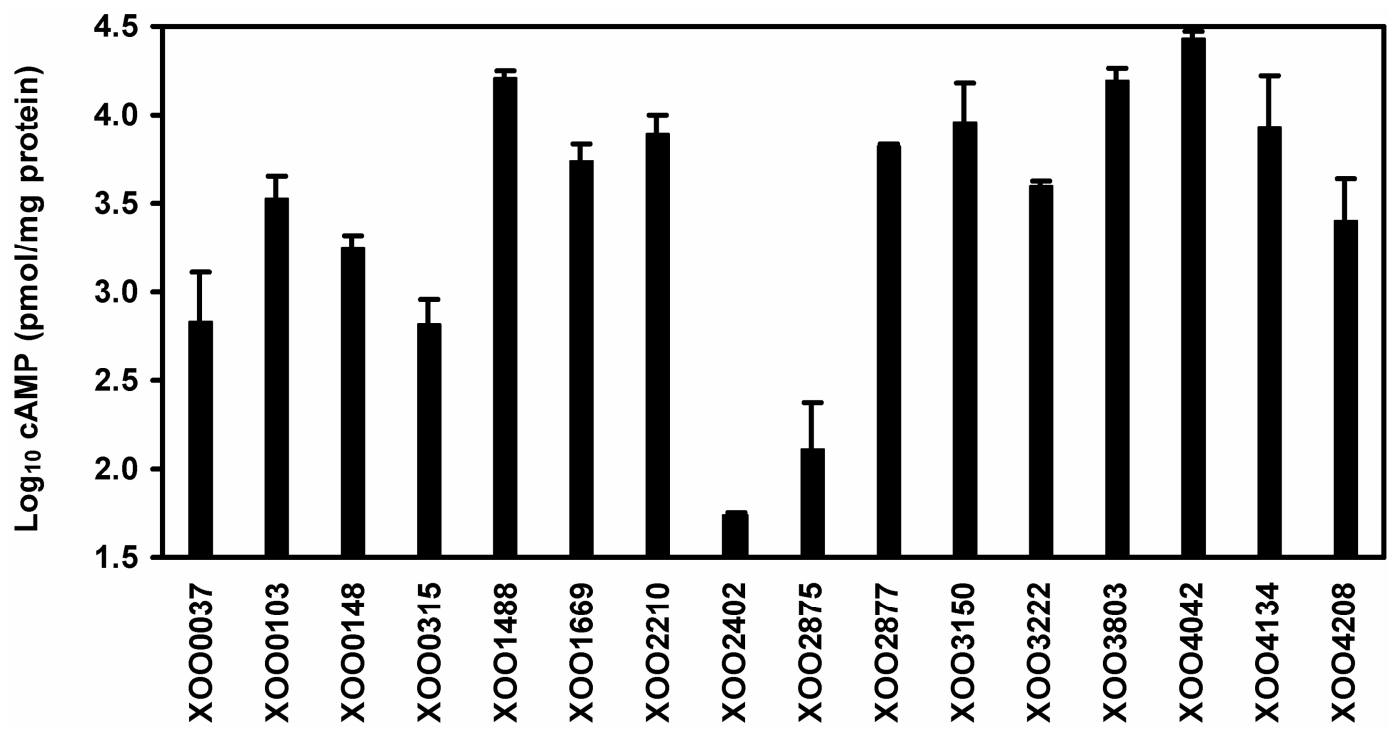

Fig. 2. Levels of cAMP in rice leaves inoculated with Xanthomonas oryzae pv. oryzae strains expressing effector::cya fusion genes. Bacterial strains with a plasmid harboring one of the effector::cya fusions were suspended with distilled water at an optical density of 1.0 at 600 nm and inoculated to rice leaves. The level of cAMP in the inoculated leaves was assayed 3 days after inoculation. Bars represent standard deviations for four leaves. Similar results were obtained in three independent experiments.

Table 2. Expression of effector::cya fusion genes in strains of Xanthomonas oryzae pv. oryzae during incubation in the hrp-inducing condition ${ }^{\mathrm{a}}$

\begin{tabular}{|c|c|c|c|c|c|}
\hline \multirow[b]{2}{*}{ Gene ID ${ }^{c}$} & \multicolumn{5}{|c|}{ Bacterial strain } \\
\hline & T7174R & 74HrpX::Km & 74HrcV::Km & 74HраB::Tet & 74HраР::Km \\
\hline XOO0037 & $11.6 \pm 6.1$ & $0.4 \pm 0.1$ & $23.9 \pm 8.3$ & $11.9 \pm 1.5$ & $11.6 \pm 1.1$ \\
\hline XOO0103 & $11,296.3 \pm 709.4$ & $16.7 \pm 3.7$ & $12,221.7 \pm 2018.0$ & $12,207.1 \pm 2712.0$ & $12,399.4 \pm 2269.4$ \\
\hline XOO0148 & $5,381.6 \pm 726.0$ & $41.5 \pm 17.0$ & $6,056.6 \pm 830.8$ & $5,364.9 \pm 336.6$ & $3,579.5 \pm 268.1$ \\
\hline XOO0315 & $307.7 \pm 32.1$ & $243.4 \pm 22.8$ & $350.6 \pm 38.1$ & $338.7 \pm 38.3$ & $190.7 \pm 14.0$ \\
\hline XOO1488 & $7474.7 \pm 1384.9$ & $22.5 \pm 4.2$ & $8,182.5 \pm 650.9$ & $10,198.4 \pm 2311.7$ & $8,853.6 \pm 2568.9$ \\
\hline XOO1669 & $817.8 \pm 52.2$ & NT & $1,015.6 \pm 27.1$ & $877.7 \pm 258.7$ & $1,007.4 \pm 401.3$ \\
\hline $\mathrm{XOO} 2210$ & $1,770.2 \pm 55.0$ & $72.9 \pm 2.3$ & $1,874.7 \pm 585.9$ & $2,966.1 \pm 92.2$ & $2,593.3 \pm 80.6$ \\
\hline XOO2402 & $12.5 \pm 0.4$ & $13.5 \pm 0.5$ & $12.2 \pm 1.1$ & $16.8 \pm 2.2$ & $19.1 \pm 5.3$ \\
\hline XOO2875 & $25.6 \pm 0.2$ & $27.6 \pm 2.3$ & $32.5 \pm 4.5$ & $23.6 \pm 10.2$ & $18.3 \pm 3.3$ \\
\hline XOO2877 & $1,419.5 \pm 207.2$ & NT & $2,238.0 \pm 460.2$ & $2,689.0 \pm 156.8$ & $2,009.2 \pm 558.1$ \\
\hline XOO3150 & $10,498.7 \pm 1541.2$ & $39.7 \pm 5.8$ & $17,169.8 \pm 333.6$ & $15,182.9 \pm 5894.6$ & $15,941.9 \pm 3354.4$ \\
\hline XOO3222 & $647.9 \pm 81.6$ & $25.9 \pm 15.5$ & $970.4 \pm 93.3$ & $897.2 \pm 144.9$ & $799.6 \pm 6.9$ \\
\hline XOO3803 & $5,536.2 \pm 141.1$ & NT & $5,513.9 \pm 1197.5$ & $9,892.5 \pm 2706.2$ & $4,668.2 \pm 798.7$ \\
\hline XOO 4042 & $19,913.0 \pm 4125.1$ & $126.1 \pm 15.0$ & $18,914.8 \pm 3918.3$ & $21,510.0 \pm 4455.9$ & $22,451.9 \pm 4651.0$ \\
\hline XOO4134 & $702.3 \pm 65.9$ & NT & $748.7 \pm 155.0$ & $1,010.1 \pm 70.6$ & $865.6 \pm 168.4$ \\
\hline XOO 4208 & $499.7 \pm 99.2$ & NT & $368.6 \pm 14.6$ & $660.1 \pm 317.0$ & $512.5 \pm 327.0$ \\
\hline
\end{tabular}

${ }^{a}$ Bacterial strains were incubated in the $h r p$-inducing medium XOM2 for $18 \mathrm{~h}$ followed by the adenylate cyclase assay.

${ }^{\mathrm{b}}$ The wild-type strain (T7174R) and the $h r p X^{-}(74 \mathrm{HrpX}:: \mathrm{Km}), h r c V^{-}(74 \mathrm{HrcV}:: \mathrm{Km}), h p a B^{-}(74 \mathrm{HpaB}::$ Tet $)$, and $h p a P^{-}(74 \mathrm{HpaP}:: \mathrm{Km})$ mutants were transformed with fusion genes. Numbers represent pmol cAMP per $1 \mathrm{mg}$ of bacterial proteins (average \pm standard deviation of three replicates). NT $=$ not tested because our previous work (Furutani et al. 2006) indicated HrpX-dependent expression of XOO1669, XOO2877, XOO3803, and XOO4208.

c The 5' region of each gene with the upstream putative promoter region is fused with cya. 
A BLASTP search using the National Center for Biotechnology Information server revealed that nine of 16 effectors identified in this study (XOO0103, XOO0148, XOO0315, XOO1669, XOO2402, XOO3222, XOO4042, XOO4134, and XOO4208) were conserved in all Xanthomonas strains whose genome have been completely sequenced: $X$. oryzae pv. oryzae strains KACC10331 and PXO99A, X. axonopodis pv. citri 306, $X$. campestris pv. campestris strains 8004 and ATCC33913, and $X$. campestris pv. vesicatoria 85-10 (Table 3) (da Silva et al. 2002; Lee et al. 2005; Qian et al. 2005; Salzberg et al. 2008; Thieme et al. 2005). Seven other effectors identified in this study were conserved in limited strains with either high or low homology. Three of these (XOO0037, XOO1488, and XOO2877) are likely to be specific to $X$. oryzae. Although these protein homologs are not found in the protein database

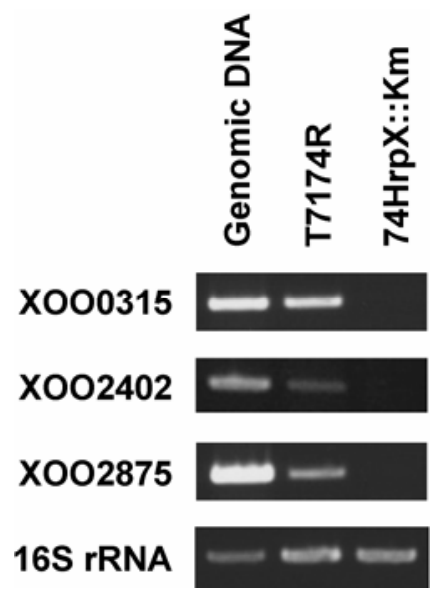

Fig. 3. HrpX-dependent expression of effector genes XOOO315, XOO2402, and XOO2875. Wild-type strain T7174R of Xanthomonas oryzae pv. oryzae or a mutant strain of the hypersensitive response and pathogenicity $(h r p)$ regulatory protein $\mathrm{HrpX}, 74 \mathrm{HrpX}: \mathrm{Km}$, was incubated in the $h r p$-inducing medium $\mathrm{XOM} 2$, and semiquantitative reversetranscription polymerase chain reaction (PCR) was performed with total RNA as a template. PCR products were electrophoretically separated on $1.2 \%$ agarose gel. The PCR products obtained from wild-type genomic DNA were used as size markers and 16S rRNA was used as a control. of KACC10331, we found highly conserved DNA sequences, and the putative translation products have high similarity with the respective proteins from MAFF311018, except for XOO2877 homolog, which contains a 1-bp gap. Also in PXO99A, XOO1488 homolog is missing in the protein database but a highly conserved DNA sequence (99\% without gap) is found. Moreover, the BLASTP search revealed that the amino acid sequences of the three effectors are highly conserved in another rice pathogen of xanthomonads, $X$. oryzae pv. oryzicola BLS256, whose genome sequencing is not completely finished yet (GenBank accessions ZP_02241549, ZP_02244325, and ZP_02243406). Interestingly, XOO2210 is conserved only in X. oryzae pv. oryzae isolated from east Asia (KACC10331 and MAFF311018). BLASTN analysis revealed that a DNA sequence similar to XOO2210 is in plasmids of $X$. axonopodis pv. citri, pXAC33 and pXAC64, but the similarity was partial; the sequence is unlikely to encode a protein with the same function as XOO2210. The homology analyses imply that the effectors conserved in all xanthomonads may have common functions in Xanthomonas spp.-plant interactions and that rice pathogen-specific effectors may function in specific interactions between rice and $X$. oryzae strains. However, no experimental evidence has been obtained.

Generally, each effector had an unremarkable effect on virulence, and the involvement of most effectors remains unclear. Among effectors that we identified, two (XOO0148 and XOO3150) were highly homologous with virulence-associated effectors AvrBs2 and XopN in X. campestris pv. vesicatoria. AvrBs2 triggers disease resistance in pepper plants that have the $B s 2$ resistance gene, which encodes the nucleotide-binding site leucine-rich repeat-type resistance protein, and, at the same time, it contributes to bacterial virulence on susceptible host plants (Casper-Lindley et al. 2002; Swords et al. 1996; Tai et al. 1999). XopN is required for full pathogenicity in pepper and tomato (Roden et al. 2004). The protein shares structural homology with a superfamily of proteins containing tandemly repeated $\alpha$-helices, known as ARM/HEAT repeats, that are found in almost all eukaryotes but are rare in bacteria (Andrade et al. 2001). XopN might use HEAT repeat structures to modulate plant signal transduction by mimicking or interfering with proteins containing these repeats. Protein XOO2875 has high

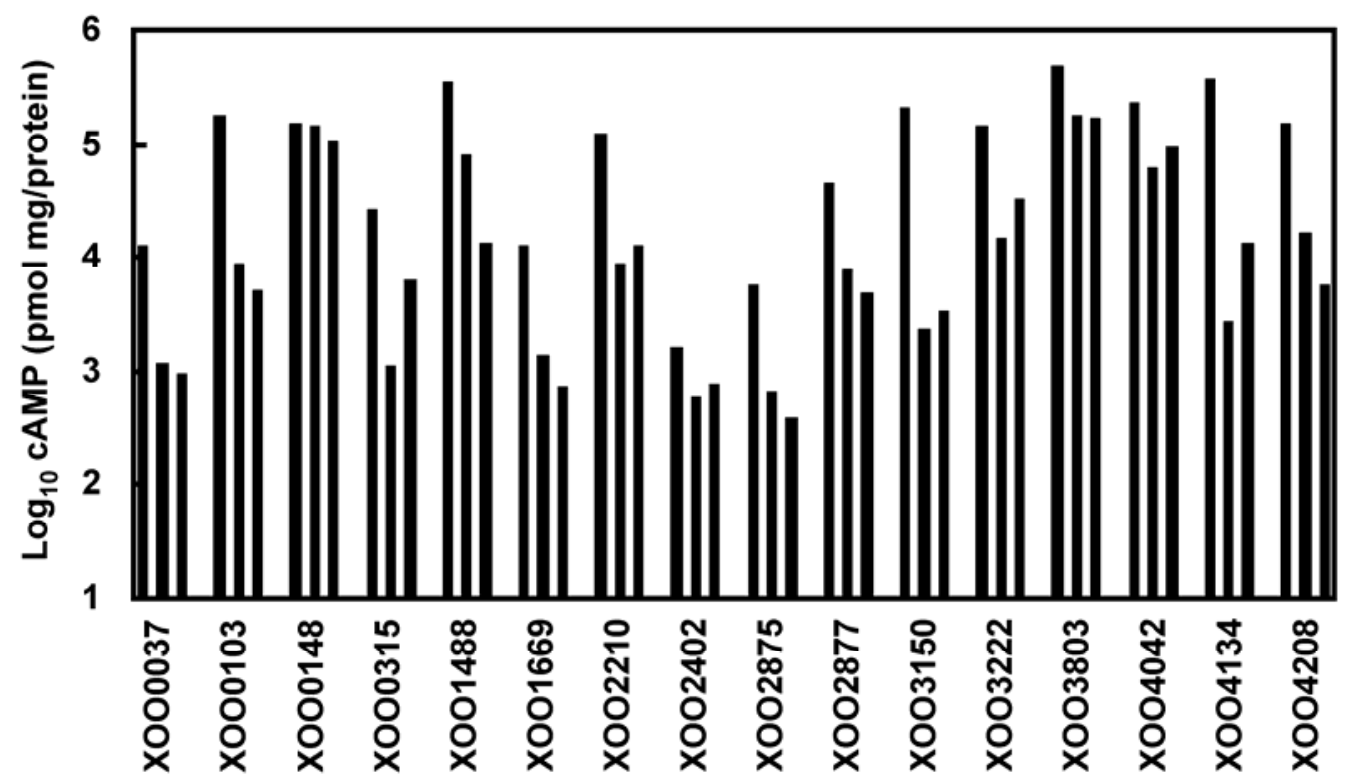

Fig. 4. Levels of cAMP in tomato leaves infiltrated with the wild type (left) of Xanthomonas oryzae pv. oryzae, the hpaB ${ }^{-}$mutant (middle), or hpaP $P^{-}$mutant (right) transformed with an effector::cya fusion gene. Accumulation of cAMP was assayed $8 \mathrm{~h}$ after infiltration. A similar result was obtained in an additional test. 
homology with the early chlorosis factor (ECF) protein (XCV3785) of X. campestris pv. vesicatoria, which is one of the T3S effectors. As its name indicates, ECF is involved in induction of early chlorosis on tomato and several nonhosts, which is one of the symptoms of bacterial spot disease caused by $X$. campestris pv. vesicatoria (Morales et al. 2005). However, a mutation in the gene ecf has no impact on bacterial growth in planta, and the relationship between bacterial virulence and production of symptoms by ECF remains unknown.
We also conducted BLASTP analysis of the effectors against other genera of bacteria and found that several effectors have homology with proteins in Acidovorax avenae subsp. citrulli, $P$. syringae strains, and $R$. solanacearum, although the homology is generally partial and limited except for XOO4208. XOO4208 is a homolog of X. campestris pv. vesicatoria XopQ and $P$. syringae pv. tomato DC3000 HopQ1-1, which are highly and broadly conserved in plant-pathogenic bacteria (Cunnac et al. 2004; Roden et al. 2004; Wei et al. 2007). These

Table 3. Conservation of Xanthomonas oryzae pv. oryzae type III effectors in other xanthomonads ${ }^{\mathrm{a}}$

\begin{tabular}{|c|c|c|c|c|c|c|}
\hline \multicolumn{3}{|c|}{ X. oryzae pv. oryzae } & \multirow{2}{*}{$\begin{array}{c}\text { X. axonopodis } \\
\text { pv. citri } 306^{\mathrm{d}}\end{array}$} & \multicolumn{2}{|c|}{ X. campestris pv. campestris } & \multirow{2}{*}{$\begin{array}{l}X . \text { campestris pv. } \\
\text { vesicatoria } 85-10\end{array}$} \\
\hline MAFF311018 & $\mathrm{KACC10331}^{\mathrm{b}}$ & PXO99A $^{c}$ & & 8004 & ATCC33913 & \\
\hline XOO0037 & NA & PXO03356 (100\%) & $\mathrm{N}$ & $\mathrm{N}$ & $\mathrm{N}$ & $\mathrm{N}$ \\
\hline XOO0103 & XOO0074 (99\%) & PXO03413 (99\%) & XAC2785 (32\%) & XC_3024 (63\%) & XCC1218 (63\%) & XCV0414 (XopF1; 82\%) \\
\hline XopF1 homolog & & & & & & XCV2942 (XopF2; 59\%) \\
\hline XOO0148 & XOO0168 (100\%) & PXO03330 (99\%) & XAC0076 (63\%) & XC_0052 (82\%) & $\mathrm{XCC} 0052(82 \%)$ & XCV0052 (AvrBs $2 ; 90 \%)$ \\
\hline AvrBs2 homolog & & & & & & \\
\hline XOO0315 & XOO0343 (99\%) & PXO02760 (99\%) & XAC2786 (63\%) & XC_0241 (82\%) & $\mathrm{XCC0231}(82 \%)$ & XCV2944 (XopN; 62\%) \\
\hline \multicolumn{7}{|l|}{ XopN homolog } \\
\hline XOO1488 & NA & NA & $\mathrm{N}$ & $\mathrm{N}$ & $\mathrm{N}$ & $\mathrm{N}$ \\
\hline XOO1669 & XOO1768 (98\%) & PXO01625 (99\%) & XAC3085 (87\%) & XC_1210 (59\%) & XCC2899 (59\%) & XCV3215 (88\%) \\
\hline $\mathrm{XOO} 2210$ & XOO4824 (99\%) & $\mathrm{N}$ & NA & $\mathrm{N}$ & $\mathrm{N}$ & $\mathrm{N}$ \\
\hline XOO2402 & XOO2543 (99\%) & PXO01041 (99\%) & XAC2009 (83\%) & XC_2210 (83\%) & XCC1975 (83\%) & XCC2059 (81\%) \\
\hline XOO2875 & XOO3022 (99\%) & PXO00234 (99\%) & $\mathrm{N}$ & $\mathrm{N}$ & $\mathrm{N}$ & XCV3785 (92\%) \\
\hline XOO2877 & NA & PXO00236 (97\%) & $\mathrm{N}$ & $\mathrm{N}$ & $\mathrm{N}$ & $\mathrm{N}$ \\
\hline XOO3150 & NA & NA & XAC2786 (57\%) & $\mathrm{N}$ & $\mathrm{N}$ & XCV2944 (XopN; 57\%) \\
\hline XOO3222 & XOO3425 (99\%) & PXO02107 (98\%) & XAC1208 (80\%) & XC_2994 (40\%) & XCC1247 (40\%) & XCV1236 (XopP; 80\%) \\
\hline XopP homolog & XOO3426 (98\%) & & & & & \\
\hline XOO3803 & XOO4033 (100\%) & PXO04172 (99\%) & XAC0601 (85\%) & $\mathrm{N}$ & $\mathrm{N}$ & XCV0657 (78\%) \\
\hline XOO4042 & XOO4287 (100\%) & PXO03702 (99\%) & $\mathrm{XAC} 0543(56 \%)$ & XC_0541 (58\%) & $\mathrm{XCC} 0529(58 \%)$ & XCV0572 (XopX; 61\%) \\
\hline XopX homolog & & & & XC_0542 (54\%) & $\mathrm{XCC} 0530(54 \%)$ & \\
\hline XOO4134 & XOO4391 (100\%) & PXO03819 (99\%) & XAC0277 (36\%) & XC_0268 (33\%) & $\mathrm{XCC} 0258(33 \%)$ & XCV0285 (38\%) \\
\hline XOO4208 & XOO4466 (97\%) & PXO03901 (96\%) & XAC4333 (91\%) & XC_3177 (61\%) & XCC1072 (61\%) & XCV4438 (XopQ; 91\%) \\
\hline XopQ homolog & & & & & & \\
\hline
\end{tabular}

a Parentheses indicate percent amino-acid identity. $\mathrm{N}=$ no gene was found. NA = not annotated.

b XOO0037, XOO1488, XOO2877, and XOO3150 were not found in the protein database in KACC10331, but homologies in the nucleotide sequence level were found as follows: XOO0037 $=100 \%$, XOO1488 $=97 \%$, XOO2877 $=99 \%$ (but it contains 1 -bp gap and resulting frameshift), and XOO3150 $=100 \%$.

${ }^{c}$ XOO1488 and XOO3150 were not found in the protein database in PXO99A, but homologies in the nucleotide sequence level were found as follows: $\mathrm{XOO} 1488=99 \%$ and $\mathrm{XOO} 3150=100 \%$.

${ }^{\mathrm{d}}$ XOO2210 sequence is conserved in plasmids pXAC33 and pXAC64, although they contain several gaps and are likely to be unfunctional.

Table 4. Characterization of the N-terminal amino-acid composition in effectors identified in this study

\begin{tabular}{|c|c|c|c|c|c|c|c|}
\hline Gene ID & Total Ser and Pro ${ }^{a}$ & Ser & Pro & Leu $^{b}$ & Asp and Gluc & Third amino acid & Fourth amino acid \\
\hline XOO0037 & 12 & 9 & 3 & 2 & 0 & $P$ & $\mathrm{~S}$ \\
\hline XOO0103 & 13 & 8 & 5 & 3 & 1 & $\mathrm{~L}$ & $\mathrm{~S}$ \\
\hline XOO0148 & 13 & 5 & 8 & 2 & 0 & $\mathrm{I}$ & $\mathrm{G}$ \\
\hline XOO0315 & 14 & 8 & 6 & 3 & 0 & $\mathrm{P}$ & A \\
\hline XOO1488 & 14 & 6 & 8 & 2 & 0 & $\mathrm{P}$ & V \\
\hline XOO1669 & 4 & 1 & 3 & 5 & 0 & $\mathrm{~L}$ & $\mathrm{~N}$ \\
\hline XOO2210 & 12 & 5 & 7 & 5 & 0 & $\mathrm{P}$ & A \\
\hline XOO2402 & 17 & 9 & 8 & 3 & 1 & $\mathrm{~S}$ & G \\
\hline \multirow[t]{2}{*}{$\mathrm{XOO} 2875^{\mathrm{d}}$} & 6 & 4 & 2 & 7 & 1 & $\mathrm{D}$ & $\mathrm{C}$ \\
\hline & 10 & 5 & 5 & 1 & 0 & I & $\mathrm{K}$ \\
\hline XOO2877 & 11 & 3 & 8 & 7 & 1 & A & $\mathrm{L}$ \\
\hline XOO3150 & 13 & 6 & 7 & 3 & 0 & $\mathrm{R}$ & $\mathrm{H}$ \\
\hline XOO3222 & 12 & 6 & 6 & 3 & 1 & $\mathrm{R}$ & $\mathrm{C}$ \\
\hline XOO3803 & 10 & 7 & 3 & 4 & 0 & I & $\mathrm{S}$ \\
\hline \multirow[t]{2}{*}{$\mathrm{XOO} 4042^{\mathrm{e}}$} & 16 & 10 & 6 & 3 & 0 & W & $\mathrm{L}$ \\
\hline & 15 & 8 & 7 & 3 & 2 & I & $\mathrm{Q}$ \\
\hline XOO4134 & 10 & 6 & 4 & 2 & 0 & $\mathrm{~T}$ & $\mathrm{~N}$ \\
\hline XOO4208 & 13 & 4 & 9 & 3 & 0 & $\mathrm{P}$ & $\mathrm{T}$ \\
\hline
\end{tabular}

a Number of Ser or Pro residues in the N-terminal 50 amino acids.

${ }^{b}$ Number of Leu residues in the N-terminal 50 amino acids.

c Number of Asp and Glu residues in the N-terminal 12 amino acids.

${ }^{\mathrm{d}}$ The XOO2875 homolog in the Xanthomonas campestris pv. vesicatoria early chlorosis factor (ECF) gene starts from ATG 369 bp upstream of the start codon of XOO2875. Both open reading frame (ORF) products, one of which starts from the start codon in the genome database (upper) and the other of which starts from the same start codon as the ECF gene (lower), were examined.

e This sequence includes a PIP box and -10 box-like motif that overlaps the $5^{\prime}$ coding region of XOO4042. Therefore, both ORF products, one of which starts from the start codon in the genome database (upper) and the other of which starts from ATG 54 bp downstream of the -10 box-like motif (lower), were examined. 
proteins have structural homology to inosine-uridine nucleoside N-ribohydrolase. The HopQ1-1 has been shown to be an avirulence determinant in Nicotiana benthamiana (Wei et al. 2007), although the correlation of its structural homology to hydrolase activity has not been clarified.

In plant-pathogenic bacteria, the expression of many effector genes depends on Hrp transcriptional regulators, and their coexpression with a T3S system during infection has been suggested (Tang et al. 2006). In xanthomonads, HrpX functions as a regulator for hrp genes, and two cis elements are located in the promoter region of many HrpX regulons; one is a PIP box and the other is a -10 box-like sequence located 30 to $32 \mathrm{bp}$ downstream of the PIP box. In previous work, we identified nine novel HrpX regulons with the two cis elements which are regulated by HrpX (Furutani et al. 2006) and, here, we have shown that five of these nine encode effectors. Moreover, expression analysis using a Cya reporter gene and semiquantitative RT-PCR analysis revealed that all the effector genes identified in this study were expressed HrpX dependently (Table 2; Fig. 3). In the predicted promoter regions of the newly identified HrpX-regulated genes (except for XOO0037, XOO2875, and $X O O 3150$ ), we found sequences similar to a set of PIP box and -10 box-like motifs, although all except XOO2402 have base mismatches from the consensus. The cis element for $\mathrm{XOO} 2402$ is too far from the start codon and, for XOO4042, overlaps the coding region according to the database for $X$. oryzae pv. oryzae MAFF311018 (Supplementary Table S4). The sequences that resemble the set of PIP box and -10 boxlike motifs might function as cis-elements. In the constructs for XOO0315::cya and XOO2402::cya, the cis elements were not completely present, and the expression of the fusion genes from the constructs were HrpX independent and weak; however, their expressions proved to be HrpX dependent by semiquantitative RT-PCR. These results may imply the importance of the cis elements for expression of the genes. In XOO0037, $X O O 2875$, and $X O O 3150$, which are not preceded by the cis elements, some other factor or factors might be involved in the HrpX-dependent expression.

Although a number of T3S effectors have been isolated from bacterial pathogens of plants and animals, secretion mechanisms via a T3S apparatus are not well understood. However, the importance of the N-terminal structures in effectors has been shown (Alfano and Collmer 2004; Lloyd et al. 2001; Schechter et al. 2004; Tampakaki et al. 2004). In the present study, 44 ORF were selected as effector candidates having three conserved export-associated patterns in the $\mathrm{N}$-terminal domain of most $P$. syringae effectors: i) a high percentage (more than 10\%) of Ser residues in the first 50 aa residues, ii) no Asp and Glu in the first 12 residues, and iii) Leu, Ile, Val, or Pro at the third and forth residues (Schechter et al. 2004). However, only seven of these ORF products proved to be translocated into plant cells. Also, in $R$. solanacearum, similar features in the N-terminal region of effectors have been suggested: i) a high percentage (more than 20\%) of Ser and Pro and a low percentage (less than 6\%) of Leu in the first 50 residues and ii) no Asp and Glu in the first 12 residues (Cunnac et al. 2004). We examined the N-terminal amino acid compositions of the $16 X$. oryzae pv. oryzae effector proteins that we identified within the $X$. oryzae pv. oryzae database (Ochiai et al. 2005). All of the effectors, except for XOO1669 and XOO2875, possess more than 10 Ser and Pro residues in the first 50 aa (Table 4), which is highly consistent with reports in $R$. solanacearum, and most of them possess more than five Ser residues, as reported in $P$. syringae. The putative start codon of $\mathrm{XOO} 2875$ is different from that of the homolog, the ECF gene, in X. campestris pv. vesicatoria (Morales et al. 2005). We expect that the start codon predicted in $X$. campestris pv. vesicatoria is more probable for $X O O 2875$ because the product from the latter start codon would have a high percentage $(20 \%)$ of Ser and Pro residues and a low percentage $(2 \%)$ of Leu residue in the N-terminus. We also examined other start codons for XOO1669 but found no translation products with Ser- and Prorich $\mathrm{N}$-termini.

In all, 13 of 16 effectors have less than three Leu residues in the first 50 aa, and almost all the effectors have either no or one Asp and Glu residue in the first 12 residues. In addition, at least one of the third and fourth residues was Leu, Ile, Val, or Pro in 12 of the 16 effectors. Taken together, all effectors agree with at least three of four criteria: i) more than $20 \%$ Ser and Pro residues, ii) less than $6 \%$ Leu residues in the first 50 aa residues, iii) no or one Asp and Glu residue in the first 12 residues, and iv) Leu, Ile, Val, or Pro at the third or fourth residues, except for XOO1669, which agrees with two of the criteria. As mentioned, XOO4042 is preceded by a set of PIP box and -10 box-like sequences; however, based on the database, it overlaps the 5'-coding region. The start codon of the XOO4042 homolog in another X. oryzae pv. oryzae strain, PXO99A, is predicted to be $84 \mathrm{bp}$ ( $28 \mathrm{aa}$ ) downstream of that predicted in MAFF311018. The translation product that starts from Met28 also has an effector-like $\mathrm{N}$-terminal amino acid composition even though it contains two Glu residues in the $\mathrm{N}$-terminal region.

A number of $\mathrm{T} 3 \mathrm{~S}$ effectors require chaperones for efficient secretion (Page and Parsot 2002; Parsot et al. 2003; Stebbins and Galan 2001). Generally, chaperone genes are located next to the corresponding genes. In xanthomonads, no typical chaperone genes have been found. As for the effectors identified in this study, there are no possible chaperone genes neighboring any effector gene. Recently, Büttner and associates (2004, 2006) reported that, in $X$. campestris pv. vesicatoria, efficient secretion of several effectors is mediated by a protein complex that contains $\mathrm{HpaB}$ and $\mathrm{HpaC}$ (called HpaP in X. oryzae pv. oryzae) and that the protein complex recruits effectors to the T3S apparatus. We showed that efficient secretion of all the effectors, except for XOO0148, requires both $\mathrm{HpaB}$ and HpaP although they are not indispensable for the secretion. The results suggest that $\mathrm{HpaB}$ and $\mathrm{HpaP}$ function as global chaperones also in $X$. oryzae pv. oryzae and that 15 of the 16 effectors identified in this study are efficiently translocated with the assistance of $\mathrm{HpaB}$ and $\mathrm{HpaC}$. How the substrates are recognized by the T3S system remains to be investigated.

In this study, we constructed effector::cya fusion genes and assayed the translocation of the products by measuring the level of cAMP in planta. However, the possibility that Cya may prevent translocation of an effector or that a fused effector protein may inhibit the adenylate cyclase activity of Cya could not be excluded. Therefore, several effectors might have been missed in this study using the reporter system. Also, the predicted start codon in the genome database information might be inaccurate for some ORF, as our data suggest. Therefore, it is likely that some effector genes with the $\mathrm{N}$-terminal secretion pattern were not selected or correctly cloned with the appropriate promoter region for the candidates. Moreover, only the first gene of each operon could be selected through the screening approach in this study, except for XOO0103 (the construct for which also includes XOO0104). Taken together, it is highly possible that $X$. oryzae pv. oryzae may harbor effectors other than those we identified in this study.

In addition to well-characterized TAL effectors, we found that at least 16 non-TAL effectors are harbored in $X$. oryzae pv. oryzae MAFF311018. Although we have not done experiments to investigate the involvement of effectors in bacterial pathogenicity, at least some of them are expected to contribute, along with TAL effectors, major or minor effects on the viru- 
lence of the bacterium. Further characterization of the effectors will help us better understand their roles in plant-pathogen interactions.

\section{MATERIALS AND METHODS}

\section{Bacterial strains and media.}

A spontaneous rifampicin-resistant mutant, T7174R (Ezuka and Horino 1974; Watabe et al. 1993), derived from X. oryzae pv. oryzae T7174, has the same pathogenicity as the parental strain and was used as the wild type in this study. Strain T7174 is the same as MAFF311018, whose genome have been completely sequenced (Ochiai et al. 2005). Strain 74HrpX::Km (formerly named $74 \Delta \mathrm{HrpXo}$ ) is a transposon insertion mutant of strain T7174R, which is deficient in an hrp regulator HrpX (Tsuge et al. 2001). Strain 74HrcV::Km (formerly named $74 \Delta \mathrm{HrcV}$ ) is a transposon insertion mutant of strain T7174R that is defective in the T3S system (Furutani et al. 2003). Strains 74HpaB::Tet, in which a tetracycline-resistance gene from pBR322 (Sutcliffe 1979) is inserted at +138 of hpaB $(+1$ represents $A$ of the initiation codon ATG), and 74HpaP::Km, in which a EZ::TN<KAN-2> transposon (Epicentre, Madison, WI, U.S.A.) is inserted at +363 of hpaP (named hpaC in $X$. campestris pv. vesicatoria), were isolated by marker exchange mutagenesis using strain T7174R. $X$. oryzae pv. oryzae strains were usually grown at $28^{\circ} \mathrm{C}$ in nutrient broth-yeast extract (NBY) medium (Vidaver 1967) or hrp-inducing medium XOM2 (Tsuge et al. 2002). For incubation in XOM2, bacterial strains preincubated on an NBY plate for 1 or 2 days were washed twice with distilled water (DW) and resuspended in DW at an optical density of 1.0 at $600 \mathrm{~nm}$. Bacterial suspension $(100 \mu \mathrm{l})$ was added to $1 \mathrm{ml}$ of XOM2 medium and incubated with shaking for $18 \mathrm{~h}$. Escherichia coli DH5 $\alpha \mathrm{MCR}$ (Gibco BRL, Gaithersburg, MD, U.S.A.) was grown at $37^{\circ} \mathrm{C}$ in Luria-Bertani broth (Sambrook et al. 1989). All media were supplemented with antibiotics at the following concentrations: rifampicin, $20 \mu \mathrm{g} / \mathrm{ml}$; ampicillin, $50 \mu \mathrm{g} / \mathrm{ml}$; cycloheximide, 50 $\mu \mathrm{g} / \mathrm{ml}$; kanamycin, $25 \mu \mathrm{g} / \mathrm{ml}$ for $X$. oryzae pv. oryzae and 50 $\mu \mathrm{g} / \mathrm{ml}$ for $E$. coli; and spectinomycin, $25 \mu \mathrm{g} / \mathrm{ml}$ for $X$. oryzae pv. oryzae and $50 \mu \mathrm{g} / \mathrm{ml}$ for E. coli.

\section{Plasmid construction.}

Plasmids expressing the effector candidate and Cya fusion proteins were generated. A short EcoRI-SmaI fragment containing EcoRI, SacI, and KpnI recognition sites was removed from pMS107, which harbors a promoterless cya gene (Sory and Cornelis 1994), by digestion with EcoRI (followed by filling in) and SmaI, and then religated. The resulting plasmid pMS107M was digested with BglII and PstI, and the approximately $1.2-\mathrm{kb}$ fragment containing a cya gene was recovered and ligated with pUC118 (Vieira and Messing 1987) digested with BamHI and PstI to give pUCCya. Also, a BglII (filled in)Pst I fragment from pMS107M was ligated with pUC118, which had been digested with BamHI (filled in) and PstI to give pUCCya+1. pUCCya was digested with KpnI, followed by filling out and religation to obtain pUCCya-1. EcoRI-HindIII fragments containing a cya gene excised from pUCCya-1, pUCCya, and pUCCya+1 were cloned into a broad-host-range vector pHM1 (Innes et al. 1988) pretreated with EcoRI and HindIII to obtain pHMCya-1, pHMCya, and pHMCya+1, respectively. The plasmids harbor a promoterless cya gene preceded by unique EcoRI, SacI, and KpnI sites (pHMCya-1 lacks a KpnI site), and pHMCya-1 lacks 4 bp, while pHMCya+1 has an additional 4 bp between the restriction sites and the cya gene compared with pHMCya.

To construct plasmids harboring a cya gene preceded by a putative promoter region and the 5 '-coding region of each effector gene candidate, we amplified the 5'-coding and -noncoding regions of the genes by PCR using appropriate primer sets added with either EcoRI, SacI, or KpnI and KOD-Plus DNA polymerase (TOYOBO, Osaka, Japan). Then, the fragments were cloned in pHMCya-1, pHMCya, or pHМCya+1, generating plasmids with each effector::cya fusion gene.

\section{Plant growth and inoculation.}

Rice (Oryza sativa cv. IR24) and tomato (Solanum lycopersicum cv. Momotaro) were grown in the greenhouse and maintained in the laboratory at $25^{\circ} \mathrm{C}(16 \mathrm{~h}$ of light and $8 \mathrm{~h}$ of darkness) during the experiments. $X$. oryzae pv. oryzae strains incubated on NBY plates were suspended at an optical density of 1.0 at $600 \mathrm{~nm}$. Fully expanded upper leaves of rice were inoculated by the clipping method (Kauffman et al. 1973) and those of tomato were infiltrated with the bacteria. Rice leaf sections ( $1 \mathrm{~cm}$ long) that included the inoculation site were collected 3 days after inoculation, and tomato leaf sections (1 $\mathrm{cm}^{2}$, including the infiltrated area) were collected 8 or $10 \mathrm{~h}$ after inoculation.

\section{Adenylate cyclase assays.}

For the assay of adenylate cyclase activity of the Cya fusion proteins expressed in $X$. oryzae pv. oryzae, strains were grown in $1 \mathrm{ml}$ of XOM 2 medium for $18 \mathrm{~h}$. The cultures were centrifuged $(10,000 \times g$ for $5 \mathrm{~min})$ and the pellets were resuspended in $100 \mu \mathrm{l}$ of B-PER (Pierce, Rockford, IL, U.S.A.) with vigorous vortexing to disrupt bacterial cells. The cellular debris was pelleted by centrifugation and removed. Adenylate cyclase activity was determined in the presence of calmodulin by using $10 \mu \mathrm{l}$ of each lysate, as described by Murata and associates (2006).

For the assay of adenylate cyclase activity in plant tissue, samples in $1 \mathrm{ml}$ of the assay buffer of the cAMP Biotrak Enzymeimmunoassay System (GE Healthcare, Buckinghamshire, U.K.) with two stainless beads $(\varphi 4.8 \mathrm{~mm})$ were homogenized using MicroSmash (TOMY Seiko, Osaka, Japan) (five times at $3,500 \mathrm{rpm}$ for $30 \mathrm{~s}$ ). During the procedure, samples were ice chilled. Homogenized samples were boiled for $5 \mathrm{~min}$. Cell debris was removed by two centrifugations $(15,000 \times g)$ each for $10 \mathrm{~min}$. The supernatant was collected in new tubes and was stored at $-80^{\circ} \mathrm{C}$ until use.

The level of cAMP in bacteria or leaf samples was quantified using the cAMP Biotrak Enzymeimmunoassay System according to the manufacturer's directions. The protein concentration of each sample was determined with a Bio-Rad protein assay kit (Bio-Rad, La Jolla, CA, U.S.A.).

\section{Semiquantitative RT-PCR analysis.}

Total RNA from bacteria cultured in XOM2 for $18 \mathrm{~h}$ was extracted with an RNeasy kit (Qiagen, Valencia, CA, U.S.A.) followed by DNase I (RNase free) (Invitrogen, Carlsbad, CA, U.S.A) treatment. After the quality of the RNA was confirmed on a $1 \%$ agarose gel, $200 \mathrm{ng}$ of each RNA sample was used for synthesis of cDNA using a reverse-transcriptase ReverTra-Ace (TOYOBO), followed by PCR with a DNA polymerase Blend Taq (TOYOBO) according to manufacturer's instructions. The following gene-specific primer sets were used: XOO0315F, 5' GGACAAGAAGCAGATCAACGACAAG-3'; XOO0315R, 5'-GACAACGGCGAACGCAGAATAC-3', XOO2402F, 5' TGCGTCGGCTTGTTGGTCAG-3'; XOO2402R, 5' GCTTGAGTGCGTTGAAAGGATTGAG-3'; XOO2875F, 5'AGAAGGTCGCTGAACTGTGGTC-3'; and XOO2875R, 5'CTGTATCGCCGTGTAGGTGTAGG-3'. Amplified fragments were visualized by staining with ethidium bromide after agarose gel electrophoresis. As a control, 16S rRNA was used. The primer set is as follow: 16S_F, 5'-GGAGGAACATCAGT 
GGCGAAGG-3' and 16S_R, 5'-CCGAAGGCACCAATCCAT CTCTG-3'.

\section{ACKNOWLEDGMENTS}

This work was supported in part by Research Fellowships for Young Scientists from the Japan Society for the Promotion of Science (no. 0600907) and the Grant for Extensive Research Program of Prefectural University of Hiroshima. We are thankful to G. R. Cornelis (University of Basel, Switzerland) for providing the plasmid pMS107 harboring a cya gene, T. Mukaihara (Research Institute for Biological Sciences, Okayama), and N. Tamura (Okayama Prefectural General Agriculture Center) for valuable suggestions.

\section{LITERATURE CITED}

Adhikari, T. B., Vera Cruz, C. M., Zhang, Q., Nelson, R. J., Skinner, D. Z., Mew, T. W., and Leach, J. E. 1995. Genetic diversity of Xanthomonas oryzae pv. oryzae in Asia. Appl. Environ. Microbiol. 61:966-971.

Alfano, J. R., and Collmer, A. 1997. The type III (Hrp) secretion pathway of plant pathogenic bacteria: Trafficking harpins, Avr proteins, and death. J. Bacteriol. 179:5655-5662.

Alfano, J. R., and Collmer, A. 2004. Type III secretion system effector proteins: Double agents in bacterial disease and plant defense. Annu. Rev. Phytopathol. 42:385-414.

Andrade, M. A., Petosa, C., O'Donoghue, S. I., Muller, C. W., and Bork, P. 2001. Comparison of ARM and HEAT protein repeats. J. Mol. Biol. 309:1-18.

Bonas, U., Stall, R. E., and Staskawicz, B. 1989. Genetic and structural characterization of the avirulence gene avrBs 3 from Xanthomonas campestris pv. vesicatoria. Mol. Gen. Genet. 218:127-136.

Buell, C. R., Joardar, V., Lindeberg, M., Selengut, J., Paulsen, I. T., Gwinn M. L., Dodson, R. J., Deboy, R. T., Durkin, A. S., Kolonay, J. F., Madupu, R., Daugherty, S., Brinkac, L., Beanan, M. J., Haft, D. H., Nelson, W. C., Davidsen, T., Zafar, N., Zhou, L., Liu, J., Yuan, Q., Khouri, H., Fedorova, N., Tran, B., Russell, D., Berry, K., Utterback, T., Van Aken, S. E., Feldblyum, T. V., D'Ascenzo, M., Deng, W. L., Ramos, A. R., Alfano, J. R., Cartinhour, S., Chatterjee, A. K., Delaney, T. P., Lazarowitz, S. G., Martin, G. B., Schneider, D. J., Tang, X., Bender, C. L., White, O., Fraser, C. M., and Collmer, A. 2003. The complete genome sequence of the Arabidopsis and tomato pathogen Pseudomonas syringae pv. tomato DC3000. Proc. Natl. Acad. Sci. U.S.A. 100:10181-10186.

Büttner, D., and Bonas, U. 2002. Getting across-bacterial type III effector proteins on their way to the plant cell. EMBO (Eur. Mol. Biol. Organ.) J. 21:5313-5322.

Büttner, D., Gürlebeck, D., Noël, L. D., and Bonas, U. 2004. HpaB from Xanthomonas campestris pv. vesicatoria acts as an exit control protein in type III-dependent protein secretion. Mol. Microbiol. 54:755-768.

Büttner, D., Lorenz, C., Weber, E., and Bonas, U. 2006. Targeting of two effector protein classes to the type III secretion system by a HpaC- and HpaB-dependent protein complex from Xanthomonas campestris pv. vesicatoria. Mol. Microbiol. 59:513-527.

Casper-Lindley, C., Dahlbeck, D., Clark, E. T., and Staskawicz, B. J. 2002. Direct biochemical evidence for type III secretion dependent translocation of the AvrBs2 effector protein into plant cells. Proc. Natl. Acad. Sci. U.S.A. 99:8336-8341.

Cornelis, G. R., and Van Gijsegem, F. 2000. Assembly and function of type III secretion systems. Annu. Rev. Microbiol. 54:735-774.

Cunnac, S., Occhialini, A., Barberis, P., Boucher, C., and Genin, S. 2004. Inventory and functional analysis of the large Hrp regulon in Ralstonia solanacearum: Identification of novel effector proteins translocated to plant host cells through the type III secretion system. Mol. Microbiol. 53:115-128.

da Silva, A. C., Ferro, J. A., Reinach, F. C., Farah, C. S., Furlan, L. R., Quaggio, R. B., Monteiro-Vitorello, C. B., Van Sluys, M. A., Almeida, N. F., Alves, L. M., do Amaral, A. M., Bertolini, M. C., Camargo, L. E., Camarotte, G., Cannavan, F., Cardozo, J., Chambergo, F., Ciapina, L. P., Cicarelli, R. M., Coutinho, L. L., Cursino-Santos, J. R., El-Dorry, H., Faria, J. B., Ferreira, A. J., Ferreira, R. C., Ferro, M. I., Formighieri, E. F., Franco, M. C., Greggio, C. C., Gruber, A., Katsuyama, A. M., Kishi, L. T., Leite, R. P., Lemos, E. G., Lemos, M. V., Locali, E. C., Machado, M. A., Madeira, A. M., Martinez-Rossi, N. M., Martins, E. C., Meidanis, J., Menck, C. F., Miyaki, C. Y., Moon, D. H., Moreira, L. M., Novo, M. T., Okura, V. K., Oliveira, M. C., Oliveira, V. R., Pereira, H. A., Rossi, A., Sena, J. A., Silva, C., de Souza, R. F., Spinola, L. A., Takita, M. A., Tamura, R. E., Teixeira, E. C., Tezza, R. I., Trindade dos Santos, M., Truffi, D., Tsai, S. M., White, F. F., Setubal, J. C., and
Kitajima, J. P. 2002. Comparison of the genomes of two Xanthomonas pathogens with differing host specificities. Nature 417:459-463.

Ezuka, A., and Horino, O. 1974. Classification of rice varieties and Xanthomonas oryzae strains on the basis of their differential interactions. Bull. Tokai-Kinki Natl. Agric. Exp. Stn. 27:1-19.

Feil, H., Feil, W. S., Chain, P., Larimer, F., DiBartolo, G., Copeland, A., Lykidis, A., Trong, S., Nolan, M., Goltsman, E., Thiel, J., Malfatti, S., Loper, J. E., Lapidus, A., Detter, J. C., Land, M., Richardson, P. M., Kyrpides, N. C., Ivanova, N., and Lindow, S. E. 2005. Comparison of the complete genome sequence of Pseudomonas syringae pv. syringae B728a and pv. tomato DC3000. Proc. Natl. Acad. Sci. U.S.A. 102:11064-11069.

Fenselau, S., and Bonas, U. 1995. Sequence and expression analysis of the hrpB pathogenicity operon of Xanthomonas campestris pv. vesicatoria which encodes eight proteins with similarity to components of the Hrp, Ysc, Spa, and Fli secretion systems. Mol. Plant-Microbe Interact. 8:845-854.

Furutani, A., Tsuge, S., Oku, T., Tsuno, K., Inoue, Y., Ochiai, H., Kaku, H. and Kubo, Y. 2003. Hpa1 secretion via type III secretion system in Xanthomonas oryzae pv. oryzae. J. Gen. Plant Pathol. 69:271-278.

Furutani, A., Tsuge, S., Oku, T., Tsuno, K., Inoue, Y., Ochiai, H., Kaku, H., and Kubo, Y. 2004. Evidence for HrpXo-dependent expression of type II secretory proteins in Xanthomonas oryzae pv. oryzae. J. Bacteriol. 186:1374-1380.

Furutani, A., Nakayama, T., Ochiai, H., Kaku, H., Kubo, Y., and Tsuge, S. 2006. Identification of novel HrpXo regulons preceded by two cis-acting elements, a plant-inducible promoter box and a -10 box-like sequence, from the genome database of Xanthomonas oryzae pv. oryzae. FEMS (Fed. Eur. Microbiol. Soc.) Microbiol. Lett. 259:133-141.

Greenberg, J. T., and Vinatzer, B. A. 2003. Identifying type III effectors of plant pathogens and analysing their interaction with plant cells. Curr. Opin. Microbiol. 6:20-28.

Gu, K., Yang, B., Tian, D., Wu, L., Wang, D., Sreekala, C., Yang, F., Chu, Z., Wang, G. L., White, F. F., and Yin, Z. 2005. R gene expression induced by a type-III effector triggers disease resistance in rice. Nature 435:1122-1125.

Gürlebeck, D., Thieme, F., and Bonas, U. 2006. Type III effector proteins from the plant pathogen Xanthomonas and their role in the interaction with host plant. Plant Physiol. 163:233-255.

Guttman, D. S., Vinatzer, B. A., Sarkar, S. F., Ranall, M. V., Kettler, G., and Greenberg, J. T. 2002. A functional screen for the type III (Hrp) secretome of the plant pathogen Pseudomonas syringae. Science 295:1722-1726.

Hopkins, C. M., White, F. F., Choi, S. H., Guo, A., and Leach, J. E. 1992. A family of avirulence genes from Xanthomonas oryzae pv. oryzae. Mol. Plant-Microbe Interact. 5:451-459.

Innes, R. W., Hirose, M. A., and Kuempel, P. L. 1988. Induction of nitrogen-fixing nodules on clover requires only 32 kilobase pairs of DNA from Rhizobium trifolii symbiosis plasmid. J. Bacteriol. 170:3793-3802.

Joardar, V., Lindeberg, M., Jackson, R. W., Selengut, J., Dodson, R., Brinkac, L. M., Daugherty, S. C., Deboy, R., Durkin, A. S., Giglio, M. G., Madupu, R., Nelson, W. C., Rosovitz, M. J., Sullivan, S., Crabtree, J., Creasy, T., Davidsen, T., Haft, D. H., Zafar, N., Zhou, L., Halpin, R., Holley, T., Khouri, H., Feldblyum, T., White, O., Fraser, C. M., Chatterjee, A. K., Cartinhour, S., Schneider, D. J., Mansfield, J., Collmer, A., and Buell, C. R. 2005. Whole-genome sequence analysis of Pseudomonas syringae pv. phaseolicola 1448A reveals divergence among pathovars in genes involved in virulence and transposition. $\mathrm{J}$. Bacteriol. 187:6488-6498.

Kamdar, H., Kamoun, S., and Kado, C. I. 1993. Restoration of pathogenicity of avirulent Xanthomonas oryzae pv. oryzae and X. campestris pathovars by reciprocal complementation with the hrpXo and $h r p X c$ genes and identification of $h r p X$ function by sequence analysis. J. Bacteriol. 175:2017-2025.

Kauffman, H. E., Reddy, A. P. K., Hsieh, S. P. Y., and Merca, S. D. 1973. An improved technique for evaluating resistance of rice varieties to Xanthomonas oryzae. Plant Dis. Rep. 57:537-541.

Koebnik, R., Kruger, S., Thieme, F., Urban, A., and Bonas, U. 2006. Specific binding of the Xanthomonas campestris pv. vesicatoria AraC-type transcriptional activator HrpX to plant-inducible promoter boxes. J. Bacteriol. 188:7652-7660.

Leach, J. E., and White, F. F. 1996. Bacterial avirulence genes. Annu. Rev. Phytopathol. 34:153-179.

Lee, B. M., Park, Y. J., Park, D. S., Kang, H. W., Kim, J. G., Song, E. S., Park, I. C., Yoon, U. H., Hahn, J. H., Koo, B. S., Lee, G. B., Kim, H., Park., H. S., Yoon, K. O., Kim, J. H., Jung, C. H., Koh, N. H., Seo, J. S., and Go, S. J. 2005. The genome sequence of Xanthomonas oryzae pathovar oryzae KACC10331, the bacterial blight pathogen of rice. Nucleic Acids Res. 33:577-586.

Lloyd, S. A., Forsberg, A., Wolf-Watz, H., and Francis, M. S. 2001. Target- 
ing exported substrates to the Yersinia TTSS: Different functions for different signals? Trends Microbiol. 9:367-371.

Morales, C. Q., Posada, J., Macneale, E., Franklin, D., Rivas, I., Bravo, M., Minsavage, J., Stall, R. E., and Whalen, M. C. 2005. Functional analysis of the early chlorosis factor gene. Mol. Plant-Microbe Interact. 18:477-486.

Murata, Y., Tamura, N., Nakaho, K., and Mukaihara, T. 2006. Mutations in the irpE gene of Ralstonia solanacearum affects hrp pili production and virulence. Mol. Plant-Microbe Interact. 19:884-895.

Niño-Liu, D. O., Ronald, P. C., and Bogdanove, A. J. 2006. Xanthomonas oryzae pathovars: Model pathogens of a model crop. Mol. Plant Pathol. 7:303-324.

Ochiai, H., Inoue, Y., Takeya, M., Sasaki, A., and Kaku, H. 2005. Genome sequence of Xanthomonas oryzae pv. oryzae suggests contribution of large numbers of effector genes and insertion sequences to its race diversity. Jpn. Agric. Res. Q. 39:275-287.

Oku, T., Alvarez, A. M., and Kado, C. I. 1995. Conservation of the hypersensitivity-pathogenicity regulatory gene hrpX of Xanthomonas campestris and $X$. oryzae. DNA Sequence 5:245-249.

Page, A. L., and Parsot, C. 2002. Chaperones of the type III secretion pathway: Jacks of all trades. Mol. Microbiol. 46:1-11.

Parsot, C., Hamiaux, C., and Page, A. L. 2003. The various and varying roles of specific chaperones in type III secretion systems. Curr. Opin. Microbiol. 6:7-14.

Petnicki-Ocwieja, T., Schneider, D. J., Tam, V. C., Chancey, S. T., Shan, L., Jamir, Y., Schechter, L. M., Buell, C. R., Tang, X., Collmer, A., and Alfano, J. R. 2002. Genomewide identification of proteins secreted by the Hrp type III protein secretion system of Pseudomonas syringae pv. tomato DC3000. Proc. Natl. Acad. Sci. U.S.A. 99:7652-7657.

Qian, W., Jia, Y., Ren, S. X., He, Y. Q., Feng, J. X., Lu, L. F., Sun, Q. Ying, G., Tang, D. J., Tang, H., Wu, W., Hao, P., Wang, L., Jiang, B. L., Zeng, S., Gu, W. Y., Lu, G., Rong, L., Tian, Y., Yao, Z., Fu, G., Chen, B., Fang, R., Qiang, B., Chen, Z., Zhao, G. P., Tang, J. L., and He, C. 2005. Comparative and functional genomic analyses of the pathogenicity of phytopathogen Xanthomonas campestris pv. campestris. Genome Res. 15:757-767.

Roden, J. A., Belt, B., Ross, J. B., Tachibana, T., Vargas, J., and Mudgett, M. B. 2004. A genetic screen to isolate type III effectors translocated into pepper cells during Xanthomonas infection. Proc. Natl. Acad. Sci. U.S.A. 101:16624-16629.

Salanoubat, M., Genin, S., Artiguenave, F., Gouzy, J., Mangenot, S., Arlat, M., Billault, A., Brottier, P., Camus, J. C., Cattolico, L., Chandler, M. Choisne, N., Claudel-Renard, C., Cunnac, S., Demange, N., Gaspin, C., Lavie, M., Moisan, A., Robert, C., Saurin, W., Schiex, T., Siguier, P., Thébault, P., Whalen, M., Wincker, P., Levy, M., Weissenbach, J., and Boucher, C. A. 2002. Genome sequence of the plant pathogen Ralstonia solanacearum. Nature 415:497-502.

Salzberg, S. L., Sommer, D. D., Schatz, M. C., Phillippy, A. M., Rabinowicz, P. D., Tsuge, S., Furutani, A., Ochiai, H., Delcher, A. L., Kelley, D., Madupu, R., Puiu, D., Radune, D., Shumway, M., Trapnell, C., Aparna, G., Jha, G., Pandey, A., Patil, P. B., Ishihara, H., Meyer, D. F., Szurek, B., Verdier, V., Koebnik, R., Dow, J. M., Ryan, R. P., Hirata, H., Tsuyumu, S., Lee, S. W., Ronald, P. C., Sonti, R. V., Van Sluys, M.A., Leach, J. E., White, F. F., and Bogdanove, A. J. 2008. Genome sequence and rapid evolution of the rice pathogen Xanthomonas oryzae pv. oryzae PXO99A. BMC Genomics 9:204.

Sambrook, J., Fritsch, F. F., and Maniatis, T. 1989. Molecular Cloning. A Laboratory Manual, 2nd ed. Cold Spring Harbor Laboratory, Cold Spring Harbor, NY, U.S.A.

Schechter, L. M., Roberts, K. A., Jamir, Y., Alfano, J. R., and Collmer, A 2004. Pseudomonas syringae type III secretion system targeting signals and novel effectors studied with a Cya translocation reporter. J. Bacteriol. 186:543-555.

Schechter, L. M., Vencato, M., Jordan, K. L., Schneider, S. E., Schneider, D. J., and Collmer, A. 2006. Multiple approaches to a complete inventory of Pseudomonas syringae pv. tomato DC3000 type III secretion system effector proteins. Mol. Plant-Microbe Interact. 19:1180-1192.

Sory, M. P., and Cornelis, G. R. 1994. Translocation of a hybrid YopE-adenylate cyclase from Yersinia enterocolitica into HeLa cells. Mol. Microbiol. 14:583-594.

Staskawicz, B. J., Mudget, M. B., Dangl, J. L., and Galán, J. E. 2001. Common and contrasting themes of plant and animal diseases. Science 292:2285-2289.

Stebbins, C. E., and Galan, J. E. 2001. Maintenance of an unfolded polypeptide by a cognate chaperone in bacterial type III secretion. Nature 414:77-81.

Sugio, A., Yang, B., Zhu, T., and White, F. F. 2007. Two type III effector genes of Xanthomonas oryzae pv. oryzae control the induction of the host genes OsTFIIA $\gamma 1$ and $O s T F X 1$ during bacterial blight of rice. Proc. Natl. Acad. Sci. U.S.A. 104:10720-10725.
Sutcliffe, J. G. 1979. Complete nucleotide sequence of the Escherichia coli plasmid pBR322. Cold Spring Harbor Symp. Quant. Biol. 43:7790.

Swarup, S., De Feyter, R. D., Brlansky, R., and Gabriel, D. W. 1991. A pathogenicity locus from Xanthomonas citri enables strains from several pathovars of $X$. campestris to elicit canker-like lesions on citrus. Phytopathology 81:802-809.

Swords, K. M., Dahlbeck, D., Kearney, B., Roy, M., and Staskawicz, B. J. 1996. Spontaneous and induced mutations in a single open reading frame alter both virulence and avirulence in Xanthomonas campestris pv. vesicatoria avrBs2. J. Bacteriol. 178:4661-4669.

Tai, T. H., Dahlbeck, D., Clark, E. T., Gajiwala, P., Pasion, R., Whalen, M. C., Stall, R. E., and Staskawicz, B. J. 1999. Expression of the Bs2 pepper gene confers resistance to bacterial spot disease in tomato. Proc. Natl. Acad. Sci. U.S.A. 96:14153-14158.

Tampakaki, A. P., Fadouloglou, V. E., Gazi, A. D., Panopoulos, N. J., and Kokkinidis, M. 2004. Conserved features of type III secretion. Cell Microbiol. 6:805-816.

Tang, X., Xiao, Y., and Zhou, J. -M. 2006. Regulation of the type III secretion system in phytopathogenic bacteria. Mol. Plant-Microbe Interact. 19:1159-1166.

Thieme, F., Koebnik, R., Bekel, T., Berger, C., Boch, J., Büttner, D. Caldana, C., Gaigalat, L., Goesmann, A., Kay, S., Kirchner, O., Lanz, C., Linke, B., McHardy, A. C., Meyer, F., Mittenhuber, G., Nies, D. H., Niesbach-Klösgen, U., Patschkowski, T., Rückert, C., Rupp, O., Schneiker, S., Schuster, S. C., Vorhölter, F. J., Weber, E., Pühler, A Bonas, U., Bartels, D., and Kaiser, O. 2005. Insights into genome plasticity and pathogenicity of the plant pathogenic bacterium Xanthomonas campestris pv. vesicatoria revealed by the complete genome sequence. J. Bacteriol. 187:7254-7266.

Tsuge, S., Furutani, A., Fukunaka, R., Kubo, Y., and Horino, O. 2001. Growth complementation of hrpXo mutants of Xanthomonas oryzae pv. oryzae by virulent strains in rice cultivars resistant and susceptible to the parental strain. J. Gen. Plant Pathol. 67:51-57.

Tsuge, S., Furutani, A., Fukunaka, R., Oku, T., Tsuno, K., Ochiai, H., Inoue, Y., Kaku, H., and Kubo, Y. 2002. Expression of Xanthomonas oryzae pv. oryzae hrp genes in XOM2, a novel synthetic medium. J. Gen. Plant Pathol. 68:363-371.

Tsuge, S., Terashima, S., Furutani, A., Ochiai, H., Oku, T., Tsuno, K., Kaku, H., and Kubo, Y. 2005. Effects on promoter activity of base substitutions in the cis-acting regulatory element of HrpXo regulons in Xanthomonas oryzae pv. oryzae. J. Bacteriol. 187:2309-2314.

Vauterin, L., Hoste, B., Kersters, K., and Swing, J. 1995. Reclassification of Xanthomonas. Int. J. Syst. Bacteriol. 45:472-489.

Vencato, M., Tian, F., Alfano, J. R., Buell, C. R., Cartinhour, S., DeClerck, G. A., Guttman, D. S., Stavrinides, J., Joardar, V., Lindeberg, M., Bronstein, P. A., Mansfield, J. W., Myers, C. R., Collmer, A., and Schneider, D. J. 2006. Bioinformatics-enabled identification of the HrpL regulon and type III secretion system effector proteins of Pseudomonas syringae pv. phaseolicola 1448A. Mol. Plant-Microbe Interact. 19:1193-1206.

Vidaver, A. K. 1967. Synthetic and complex media for the rapid detection of fluorescence of phytopathogenic pseudomonads: Effect of the carbon source. Appl. Microbiol. 15:1523-1524.

Vieira, J., and Messing, J. 1987. Production of single-stranded plasmid DNA. Methods Enzymol. 153:3-11.

Watabe, M., Yamaguchi, M., Furusawa, I., and Horino, O. 1993. Virulence, and bacterial multiplication and movement in rice leaves of Xanthomonas campestris pv. oryzae mutants impaired in productivity of extracellular polysaccharide. Ann. Phytopathol. Soc. Jpn. 59:544-550.

Wei, C. -F., Kvitko, B. H., Shimizu, R., Crabill, E., Alfano, J. R., Lin, N.C., Martin, G. B., Huang, H. -C., and Collmer, A. 2007. A Pseudomonas syringae pv. tomato DC3000 mutant lacking type III effector HopQ1-1 is able to cause disease in the model plant Nicotiana benthamiana. Plant J. 51:32-46.

Wengelnik, K., and Bonas, U. 1996. HrpXv, an AraC-type regulator, activates expression of five of the six loci in the hrp cluster of Xanthomonas campestris pv. vesicatoria. J. Bacteriol. 178:1061-1069.

Wu, X. M., Li, Y. R., Zou, L. F., and Chen, G. Y. 2007. Gene-for-gene relationships between rice and diverse avrBs3/pthA avirulence genes in Xanthomonas oryzae pv. oryzae. Plant Pathol. 56:26-34.

Yang, B., Zhu, W., Johnson, L. B., and White, F. F. 2000. The virulence factor AvrXa7 of Xanthomonas oryzae pv. oryzae is a type III secretion pathway-dependent nuclear-localized double-stranded DNA-binding protein. Proc. Natl. Acad. Sci. U.S.A. 97:9807-9812.

Yang, B., Sugio, A., and White, F. F. 2006. Os 8 N3 is a host disease-susceptibility gene for bacterial blight of rice. Proc. Natl. Acad. Sci. U.S.A. 103:10503-10508.

Zhu, W., Yang, B., Chittoor, J. M., Johnson, L. B., and White, F. F. 1998. AvrXa10 contains an acidic transcriptional activation domain in the 
functionally conserved C terminus. Mol. Plant-Microbe Interact. 11:824832.

Zwiesler-Vollick, J., Plovanich-Jones, A. E., Nomura, K., Bandyopadhyay, S., Joardar, V., Kunkel, B. N., and He, S. Y. 2002. Identification of novel hrp-regulated genes through functional genomic analysis of the Pseudomonas syringae pv. tomato DC3000 genome. Mol. Microbiol. 45:12071218 .
AUTHOR-RECOMMENDED INTERNET RESOURCES

P. syringae Genome Resources home page: pseudomonas-syringae.org/ $X$. oryzae pv. oryzae strain MAFF311018 genome database: microbe.dna.affrc.go.jp/Xanthomonas/blast/blast.html

The National Center for Biotechnology Information BLASTP search server: http://www.ncbi.nlm.nih.gov/blast/Blast.cgi 